\title{
Has BRICS lost its appeal? The foreign policy value added of the group
}

\section{Malte Brosig ${ }^{1}$ (D)}

Accepted: 23 June 2021

(c) The Author(s), under exclusive licence to Springer Nature Limited 2021

\begin{abstract}
Just after a decade of its existence, the BRICS group and the rising powers narrative have lost some of their appeal. The economic growth story has stalled, and domestic political challenges curb the group's foreign policy potency. In the context of the presumed decline of relevance, the article asks what foreign policy value is BRICS providing for its members? An inner-group perspective is applied. The article argues that BRICS is offering a number of benefits. Namely: indirectly supporting domestic regime stability, protection from unwanted external interferences, flexible alignment in foreign policies and boosting of regional authority. The article goes through the rhetorical codification of BRICS summit documents, traces the uncodified principles of cooperation among its members and illustrates its argument with selected empirical examples. Far from being in decline, BRICS delivers important value added for the group which often goes missing in the literature on regional powers.
\end{abstract}

Keywords BRICS $\cdot$ Regional Powers · Foreign policy

\section{Introduction}

The first decade of the new millennium has seen an impressive growth of research around the narrative of rising, emerging and regional powers (Destradi 2010; Gray and Murphy 2013; Hart and Jones 2010; Nolte 2010; Hurrell 2006; Wigell 2016). At the center of attention is often the BRICS group and its member countries (Stuenkel 2015a). Expectations were high toward the building of a post-western world order incorporating substantial reforms of global governance institutions (Stuenkel 2015b). The rapid and dynamic economic growth seemed to give the group significant future political weight. It was rather the question when not if BRICS would occupy a central role in global politics.

Malte Brosig

malte.brosig@wits.ac.za

1 Department of International Relations, University of the Witwatersrand, Johannesburg,

South Africa 
However, more than a decade later the jubilee moments are over. Not only has interest slipped, but also the recent narrative has turned around and research has run into a number of theoretical and practical problems as shown by Garzon (this special issue). Now, publications are more critical of the rising powers narrative (PrysHansen and Nolte (2016). While critique against the grouping is not new, it is the general tone which has changed casting doubts about the relevance and potential of the grouping to shape major events, acknowledging that the path to global and regional leadership is much more uneven than previously anticipated (Pant 2013). Despite a somehow more negative but maybe just more realistic assessment most recent studies on the issue do not per se question the relevance of rising/regional powers but acknowledge their practical limitations (see Frazier and Prys-Hansen, this issue).

In the recent past, domestic challenges have curbed the ability of at least some group members to project power. This could be seen in the cases of Brazil and South Africa (Kenkel 2016; Pauw 2017). The two countries were going through a phase of sustained public protest, mis-management and economic stagnation. Likewise Russia has experienced an economic downturn and the Chinese supercharged growth period is nearing its end, while India is not able to leave the shadow of Chinese dominance. In fact, China's hegemonic aspirations in the region are increasingly becoming a domestic political issue for India as one could observe in the strong reactions to the border standoff in summer 2020 (Saran 2020). Disparities within the BRICS are not closing. China and Russia display an increasing eagerness to assume their role as great powers, while India, Brazil and South Africa appear as limited in their external power projection (Brosig 2019).

The outbreak of COVID-19 constitutes a global shock and is without a doubt the greatest challenge for all countries at the beginning of the new decade. While it is still too early to draw any final conclusions about the effects of the pandemic on global order, it is no exaggeration to assume a lasting and profound impact. The severity of the human and economic crisis will leave deep traces both in the developed and developing world. More likely than not, the narrative of rising powers needs rethinking in a global down-turn. BRICS countries have been particularly hard hit by the virus, India, Brazil and South Africa are displaying one of the highest infection rates in their respective regions (Worldometer 9 April 2021).

This context provides an opportunity for re-investigating the role of BRICS in global order. The article aims at depicting a more nuanced analysis which supersedes and complements the sometimes binary debate which was often applying a Westerncentric (external) perspective discussing if rising powers would either bandwagon or challenge traditional centers of power (Kahler 2013). Parts of the BRICS literature is exploring the question to which extent it is revisionist or conformist (Breslin 2013; Lipton 2017). In the end, this question rather applies an external benchmark to the group instead of discussing its internal value as a foreign policy instrument for the group members. Central for this article is the question what political value is the group producing for its members? If BRICS is meaningful, depends less on how it is externally attributed influence but on its ability to generate value added for its members based on their needs and preferences. The emphasis on the internal perspective of regional powers is slowly gaining momentum (see Fawcett and Jagtiani 
this issue) and may help to revitalize research on regional powers (see Frazier and Prys-Hansen, this issue).

The current global political context in which BRICS is operating has changed markedly. The often denounced crisis of multilateralism marked by a relative (sectoral) but not substantial (system collapse) challenges to the rules-based order, and return of great power rivalry may provide both opportunities and challenges for BRICS (Eilstrup-Sangiovanni and Hofmann 2020). It provides challenges because the rise of most of its members was facilitated by liberal economic structures of global governance which now appear under stress and opportunities as the Western dominance in the global system continues to erode.

Tracing the operating principles of BRICS empirically is no easy task because of the absence of formally agreed explicit rules. This means no 'smoking gun' evidence can be provided for the categorization presented. The greater puzzle consists of an analysis of official BRICS group statements as well as individual member state positions. At least at summit level, BRICS countries are meeting annually and are issuing declarations. Since the 2012 Summit in Delhi which was entitled "BRICS Partnership for Global Stability, Security and Prosperity," security issues are figuring prominently. These Summit Declarations have increased in size and sophistication over the years now consisting of around 40 pages with an explicit section on security which will be the main focus of this article. Reference to a wide range of global security crises is common independent of the Summit's main theme which is changing annually. As BRICS is no international organization and group action is rather the additive sum of individual preferences, which emerge without needing formal decision-making processes, it is notoriously difficult to explore. Often it is easier to identify what BRICS is not than extrapolating a clearly formulated set of principles as the group is no formal treaty organization. In addition to document analysis, the article also draws on the author's participation in BRICS meetings such as Academic Forum 2018 in Johannesburg, informal conversations with diplomats involved in BRICS meetings and research visits to all five BRICS countries. While these personal impressions are inherently subjective, they are key to discover implicit working mechanisms of the group given their informal character. Lastly operating principles can also be observed through empirical observation in action with regard to key foreign policy events. Here, the assumption is that patterns of similar behavior are not random occurrences but might be seen as expression of commonly held principles.

\section{The BRICS foreign policy value added}

The article argues that BRICS does provide for a number of tangible advantages. The manner in which BRICS is operating including the formal declaratory goals, the informal non-codified principles as well as the concrete diplomatic responses to different crises does provide tangible benefits which are insufficiently reflected in the literature. The article's perspective is one of rather classical foreign policy analysis (Hudson 2005). In this regard, it is actor-centered and concentrating on how BRICS countries are designing their foreign relations to one another and assuming they do it 
in a manner which is favorable to them. Theoretically the functioning of BRICS as a foreign policy grouping is rooted in rational institutionalism with its emphasis on the principal-agent relationship (Shepsle 2008). Because BRICS is only a grouping and no organization, it is expected to directly correspond to the needs and preferences of its constitutive members. There is no independent agency of BRICS apart from its members. Within the BRICS format, the principals are directly managing the group. This results from the rather neo-Westphalian orientation of the group prioritizing an orthodox understanding of sovereignty favoring a state-led approach. In such a context, rational institutionalism as applied in research on International Organizations can be a helpful indicator when exploring the BRICS. The rational perspective assumes that group action is based on some kind of equilibrium outcomes. In other words, BRICS needs to reflect commonly shared interests of its stake-holders in order to produce club benefits. Furthermore, the group is designed and operating according to principles which promote and secure these benefits. In this context, the article names and identifies four empirically derived but also conceptually grounded club goods which provide foreign policy value. These are:

First, indirect support for domestic regime stability. As a number of BRICS countries are going through turbulent times, domestic regime stability becomes a strategically important goal also reflected in their foreign policy. The article argues that the BRICS grouping is contributing to these domestic needs. Above all, through its operating principles it creates a friendly international environment free of any critique of domestic affairs, which, in the end, supports existing political structures rather than challenging them. Especially because BRICS countries are going through domestically turbulent times, the groupings foreign policy value becomes relevant when it is able to reduce external risks to domestic challenges.

Second and linked to the first condition, it is argued that the value of BRICS further rests on its ability to shield off unwanted external interferences. While most of the literature assesses the value of BRICS with regard to its ability to shape or influence global events, this perspective might not be the ultimate (internal) benchmark according to which BRICS would measure success themselves. A more moderate (realistic) perspective would also emphasize the ability to which extent externally formulated policy preferences have not succeeded in global affairs relevant to individual BRICS members. In other words, has BRICS succeeded to halt or change unwelcome events and trends?

Third, there is an emerging consensus or at least awareness that the transforming world order is shaped by a multi-layered system of governance which is rather decentered, multiplex, multi-order, multipolar or even non-polar (Acharya 2014; Blagden 2015; Flockhart 2016; Haas 2008). In other words, however, the world order finally will look like, it is clear that the steering capabilities of individual actors, even for relatively powerful states, are limited. Here, the ability to forge flexible and multiple alignments instead of static blocs is critical. It can be argued that the internal working mechanisms of BRICS are designed in a manner which allow for this flexibility as BRICS is not designed in terms of classical bloc building. Being a member of BRICS does not preclude close relations to traditional centers of power. 
Boosting regional authority of BRICS members and carving out of regional backyards forms a forth advantage. Maybe the most tangible benefit is provided with reference to the opportunity to leverage regional power or at least boost ones image. The often criticized geographical disadvantage of BRICS not forming a coherent regional bloc but being spread around the global is not necessarily a disadvantage but can also be of value as mutual recognition for regional priorities enable group members to craft regional backyards and therewith uplift a country's regional standing.

These four attributes are primarily derived from empirical observation following an inductive logic of research and will be explored further below. However, they easily link up to various theoretical discussions. The value of regime boosting effects of regional organizations in the developing world is well documented by Herbst (2007) and Söderbaum (2013: 13). The strong emphasis on sovereign independence is rooted in the de-colonial tradition which BRICS countries are following. For example formulated in the Bandung Conference of 1955 and 2005 (Rakove 2018). The building of regional zones of influence also reflects upon the realist school of thinking with its emphasis on power politics, balancing and realpolitik. The need for flexible alignment simply evolves out of the multipolar order that is emerging and which requires regional powers to diversify their foreign relations. The BRICS grouping is designed in a manner to cover these four areas. Thus, one can argue that as long as BRICS in its current form provides for these benefits, its institutional sustainability and relevance is not under severe pressure.

These four attributes might not appear with equal relevance for each group member, but examples for each member can be found empirically. In other words, it is not argued that the four categories will need to permanently be present for everyone but that individual members can profit from them in different contexts. Before the article provides samples for each category, the following section explores the inner-working mechanisms of the group. This is essential because these inner mechanisms are primarily responsible for providing foreign policy value and are linked to the four categories mentioned. Given the extending scope of the group, it becomes nearly impossible to focus on BRICS as such and thus, a more policy specific focus is warranted. Therefore, the article focusses on the field of (international) politics and security.

\section{BRICS formal operating principles}

Generally speaking, one can distinguish between two types of operational principles (Table 1). The first type is semi-codified. Although BRICS does not have a founding charter or treaty, the aims and principles of the group are reflected in the official group statements often in the form of summit declarations. The sum of these statements can be treated as a soft kind of codification but without assuming any legal quality as formal treaties would entail. We can also distinguish between internal operational principles and world order views. Both are partially interlinked, for example the strong emphasis on classical state sovereignty informs the functioning 
Table 1 BRICS operating principles

\begin{tabular}{|c|c|c|}
\hline & Semi-codified principles & Informal rules \\
\hline Internal operation & $\begin{array}{l}\text { BRICS is a state-led process } \\
\text { Favoring multi-polarity } \\
\text { Rule-based order } \\
\text { BRICS is no strategic alliance }\end{array}$ & $\begin{array}{l}\text { Do not openly criticize a member, avoid } \\
\text { contestation } \\
\text { Do not talk about domestic opposition/prob- } \\
\text { lems } \\
\text { Provide a safe international environment for } \\
\text { leaders } \\
\text { Consensus rule } \\
\text { Promote a non-Western identity } \\
\text { Mutually accept national interests in inter- } \\
\text { national relations (carving out of regional } \\
\text { backyards) }\end{array}$ \\
\hline Global order views & $\begin{array}{l}\text { Ideally unconstrained sover- } \\
\text { eignty } \\
\text { Sovereign equality } \\
\text { Opposition against unilateral } \\
\text { (western) military interven- } \\
\text { tions } \\
\text { Favoring multi-polarity } \\
\text { Rule-based order }\end{array}$ & \\
\hline
\end{tabular}

of BRICS as a group as well as it is the preferred world order system. The second type is un-codified principles or informal norms according to which the group operates. They are only internally orientated. Even without a formal adoption of a code of conduct, BRICS meetings reflect upon unwritten rules which informally shape the group and are no less important.

BRICS is by design no policy implementing agency but rather a loose foreign policy grouping. It therefore makes little sense to lament about its missing agency or the absence of clearly formulated strategies or action plans. All these remain outside the intended purpose of the group. In fact, Gvosdev (2012) finds that: "One of the advantages of the BRICS process is that it remains a loose association of states with somewhat disparate interests, so no effort is made to force a common position when the BRICS states cannot agree on one. But these states have also found a way to disagree on some key issues...without torpedoing the entire enterprise."

Historically, the BRICS group has its normative and conceptual roots in the nonalignment movement and the Bandung Conference. The BRICS narrative, which cross-cuts its summit meetings and declaration, is the critique issued against a Western-dominated global order resembling the Bandung principles (Pham and Shilliam 2016). These include a strong emphasis on sovereign equality of all nations, territorial integrity, non-intervention and a non-coercive style of international diplomacy and rejection of neo-imperial behavior (Vieira 2012: 323). In essence, BRICS has a neo-Westphalian understanding of sovereignty and international relations which is aimed at countering unwelcome Western dominance in the global system (Thakur 2014: 1814). In this context, selective use of liberal and humanitarian rhetoric to justify military interventions in sovereign states in non-Western countries is often mentioned. Therefore, a neo-Westphalian notion of sovereignty is preferred as a shield 
against unwanted external interference. This can for example be seen in the insistence of a "Syrian-led" political process in combination with demands of respecting Syria's sovereignty and territorial integrity (Delhi Declaration 2012, para. 21). In practice, this position has favored Assad and coheres with Russian geopolitical interests in the region which can be criticized itself for not cohering to sovereignty right of Ukraine.

BRICS is "pursuing a global order in which great power is contained so that it is impossible for one state, or group of states, to impose their specific ideology on the rest of the system, or impossible to manipulate the international system to serve their national interests without regard for the common interests of states." (De Coning et al. 2015: 3). In order to provide such a shield against unduly external interference, sovereignty is understood to be fairly unconstrained. Equally important it also helps concealing internal weaknesses by denouncing external interferences in domestic politics. This becomes especially important when domestic regimes are under pressure or fear for their future stability and influence. With regard to global affairs, it is seen as an instrument that prevents hegemonic domination of the global order by single (often Western) countries or political blocs (De Coning et al. 2015: 47). In the cases of Libya and Syria, BRICS countries made it clear that they "condemn unilateral military interventions and economic sanctions" (BRICS eThekwini Declaration 2013, para 24-31). A strong emphasis on classical sovereignty in foreign affairs also signals a domestic preference for state-led politics. Unsurprisingly, the more than 100 BRICS meetings which are organized annually are in principle state-organized events. The 2019 Brasilia Declaration even mentioned "the imperative that international organizations be fully driven by Member States (...)" (BRICS Brasilia Declaration, 2019, para. 6).

Sovereignty is linked to equality and demands for truly equitable multilateralism. The call for more democratic international relations is primarily a call for more equitable participation of sovereign states, in other words more BRICS participation. The combination of the BRICS narrative on global order as based on unconstrained sovereign equality fosters a multipolar order a common theme which appears in almost every summit declaration (Ibid.).

BRICS summit declarations often refer to sovereignty in the context of global order politics in situations of crisis and armed conflict. During the 2011 Sanya Summit, BRICS declared "that the use of force should be avoided" and that "the independence, sovereignty, unity and territorial integrity of each nation should be respected" (Ibid, para 9). Because BRICS feel at a relative power disadvantage against major Western powers sovereignty is seen from a non-interference perspective. The call for non-punitive diplomacy understood as a rule-based order emerges out from a historically rooted normative belief (e.g., Bandung principles) but also satisfies a realist world view in which the BRICS aims at curbing the use of power politics if it is not in their advantage.

In the area of security, we should assume that questions of national sovereignty play a fairly dominant role, more than in areas of technical economic cooperation. In many regards, the BRICS group is the addition of agreeable individual positions. In this context, it is worth remembering that BRICS emerged from a collectively held critique of global governance structures and not because of naturally converging 
security interests. Thus, the formulation of bloc-like strategic goals was never at the center of the group's normative foundation nor is it an intended future target. BRICS is explicitly no alliance.

\section{BRICS informal operating principles}

Naturally, informal rules are more difficult to observe, and they are forming part of the internal decision-finding process but without being explicitly formulated. They are guiding principles which steer from the background. When closely observing BRICS meetings, one can explore a number of these informal principles.

First, it is apparent that at BRICS meetings' delegates do not openly criticize one another and this despite existing tensions for example between India and China. Group members informally agree not to incapacitate the grouping by importing their bilateral conflicts. The most illustrative example might be the 2017 Xiamen summit. In 2017, India and China were embroiled in a border dispute which was short before escalating militarily (Safi 2017). The approaching summit in China would have been impossible to hold if the standoff would have escalated into armed conflict even if limited in scale. A summit without Prime Minister Modi, postponement or even cancellation would have been compromising for the summit host and the group as such. In the end, a pragmatic response was found. Although the border dispute is not settled (in 2020 similar incidents occurred), both sides agreed not to escalate it further. At the summit, the issue was not mentioned at all.

This is not a single coincidence. Potentially conflictive issues are generally excluded from group deliberations. BRICS declarations will generally not touch upon issues like the status of Kashmir, the South China Sea or the Himalayan border. Not discussing conflictive issues within the BRICS format enables the group to continue cooperating despite sometimes having antagonistic positions. For example, while India on a bilateral level rejects the Chinese belt and road initiative (BRI), both countries cooperate within the framework of the New Development Bank (NDB) which mostly finances larger scale infrastructure projects similar to the BRI.

The absence of criticism does not only refer to issues of foreign policy but extends into domestic politics. The neo-Westphalian notion of sovereignty builds on the principle of non-interference into domestic affairs. Thus BRICS will not discuss any domestic political issues which are potentially conflictive or compromising. Given the different regime types ranging from liberal democracy to autocracy, BRICS does not promote a certain type of governance model nor does it evaluate merits or problems arising out of domestic governance. This is a silent agreement which avoids confrontation and works toward domestic regime stability. BRICS meetings are essentially also an opposition free zone. It is not expected that governments are challenged for their handling of domestic politics.

Also informally agreed is the principle that all decisions and final outputs are taken by consensus (participant observation). Because technically speaking, 
there is no voting and it is difficult to speak about decision-making in the first place. BRICS formal outputs are thus rather an example of agreement than resulting from compromise, bargaining or fighting about an issue. The consensus rule is important because it is potentially able to moderate the existing vast power differences between BRICS members. It also gives every member a chance of shaping the agenda and protecting/developing key national interests. BRICS is designed to prevent unexpected surprises from the group but can work as a foreign policy amplifier. Within a small setting like BRICS, the consensus rule is not automatically an inhibiting condition but an instrument of control. The consensus rule essentially provides leaders with a safe international environment with which they also associate an image gain. Each country can claim to be a member of a recognized group which provides mutual respect and support. This is often contrasted by other settings and occasions in which BRICS countries can be the target of criticism, suspicion and contestation regarding their domestic politics, regime type, foreign policy, etc., and which is often internally perceived as being un-just or mis-led critique.

BRICS formulates and implicitly promotes a non-Western identity. While Western hegemony in international relations is seen critically, the proposed remedy is not counter bloc-building. In this regard, the inner working mechanisms are forming a certain (not total) contrast to Western organizations. At the center is neo-Westphalian sovereignty, the consensus rule and emphasis on non-conflictive cooperation. While this puts certain limitations on the group, it is no regulatory or monitoring body. The non-Western group identity is rather defuse than specific.

BRICS's implicit operating principles provide the advantage of creating and accepting regional authority. BRICS meetings are designed not to challenge and criticize its members but to respect individual interests. Bi-lateral grievances or conflictive issues are omitted, and decision-making is agreed by consensus without formal procedures. Taken together, these principles can facilitate the carving out of regional backyards. As long as no other BRICS member is infringed by another one, essential individual national interests are tacitly accepted. Regional ambitions by its members are often only indirectly supported by not undermining them. This is not automatically a sign of institutional weakness or undecidedness but can work out as advantage. The absence of a clearly formulated critique in cases in which Western powers have taken explicit positions (e.g., Crimea, Syria, etc.) indirectly uplifts geopolitical ambitions of group members but at the same time, in the absence of blocbuilding efforts, provides opportunities for multiple alignments beyond the Global South.

\section{The prerogative of domestic regime stability}

The BRICS grouping is designed in a manner to help facilitate domestic regime stability. It is doing this rather indirectly and not through specific policy plans in direct support of governments. The need for domestic stability forms part of the group design and is reflected in the operating principles and world order views. Interestingly, the rising powers narrative has often overlooked the fact that the rise to 
international rank also requires domestic political stability. It was often just assumed to be unproblematic. However, domestic regime stability maybe the most important pre-condition which enables these countries to use power internationally. Thus, foreign policy needs to reflect upon these domestic needs to some degree. Seen from the perspective of existing challenges to government power, a grouping like BRICS becomes internally meaningful if it reduces external risks to internal challenges.

Although it is true that the political systems in BRICS countries are fairly stable, none of the five countries is close to regime failure, and all five countries face significant internal risks and challenges to their governments. Brazil, for example, was going through years of unrest between 2014 and 2018. President Rouseff's second term has seen long-lasting mass protest. In the end, she was impeached on dubious legal grounds by Michel Temer (2018-2019) but protests continued until Bolsonaro was elected in 2019. This prolonged phase of domestic instability incapacitating the country's foreign policy which under Lula da Silva (2003-2010) was expanding beyond its classical confines (De Almeida 2010). In South Africa, the plundering of state owned enterprises, nepotism and corruption that was accompanying President Zuma's (2009-2018) term and was driving the country into a political and economic stasis (Zondo Commission). Brazil and South Africa continue to experience one of the world's highest homicide rates, and economic inequality in both countries remains mostly unsolved and a source for political instability. In India, a Hindu nationalist candidate, Narendra Modi, was elected twice as Prime Minister (2014 and 2019). His Hindu politics do maintain or even increase domestic tensions with the country's sizeable Muslim minority (Kim 2017). In 2020, the Covid-19 pandemic saw the economy shrinking by around ten percent for a country with the greatest population pressure within the group and overcoming poverty remains the most important domestic challenge. Generally speaking, the COVID-19 pandemic is aggravating the social economic situation of millions of people in all BRICS countries maybe with the exception of China increasing popular pressure on governments. For India, tensions with Pakistan over Kashmir and regional competition with China further increase domestic political pressure. In Russia, domestic dissatisfaction with social reforms has challenged the Kremlin. A certain degree of Putin fatigue after more than 20 years in power is tangible as he proceeds to stay in power through constitutional reforms for years to come. The poisoning of the main opposition leader, Alexei Navalny, demonstrates the unwillingness for domestic political reforms. Since Western sanctions have been imposed on Russia after 2014, the population suffered visible income declines (Kluge 2019). In China, protest in Hong Kong is challenging the CCP's claim to power not only over the city state. More importantly, the Western Chinese province of Xinyang with its Muslim Uighur population is increasingly seen as a general security risk for the whole country. President Xi finds "social stability will suffer shocks, the general unity of people of every ethnicity will be damaged, and the broad outlook for reform, development and stability will be affected" if violent extremism is not contained (Ramzy and Buckley 2019). In other words, the Uighur thrust for more political independence is judged as a significant internal security threat. Internationally, China is being criticized for mass-detention camps it is building in this province. 
One mechanism through which domestic regime stability is nurtured is the statedriven nature of BRICS meetings and its informal operating principles. BRICS meetings are not the place in which opposition groups can leverage influence. To the opposite, BRICS meetings are mostly state-controlled. Critique on domestic politics is generally not welcome or part of group activities. The consensus rule and neo-Westphalian interpretation of state sovereignty work as a protection mechanism. BRICS fear and fundamental rejection of regime change interventions following the Arab Spring in Libya and Syria is not only a foreign policy position of global order dimension but also emanates out of fear of contagion (Abdenur 2016). By providing a friendly environment for heads of state displaying consensus and mutual backing, BRICS is having a (modest) regime stabilizing effect. For example, President Zuma's series of corruption scandals was increasing public pressure on the ruling party and led to the ANC loosing electoral support in most metropolitan areas. In such a situation, the prestige and recognition of deliberating within a group of global powers might partly ease domestic pressure assuming a friendly environment is provided. For South Africa as the economically smallest country, the BRICS membership meant a significant uplifting of its foreign policy standing, a positive legacy that is attributed to the Zuma administration which was facing increasing domestic pressure which led to his resignation. At least the counterfactual argument holds some value. Would BRICS have provided a platform for opposition leaders, come up with an anti-corruption policy and publically castigate domestic failures, the group would have seriously increased pressure for action and further shorten Zuma's presidential term. Surely the domestic stability effect is nearly impossible to quantify and should not be overrated, but the group's design features reflect upon the need to stabilize governments, shield them from criticism and not provide reasons to replace them.

\section{Protection against unwanted interferences}

This benefit is akin to the above but refers to foreign policy and global order issues. As BRICS is in itself not a formal alliance of like-minded states or implementing agency, it will be limited in its ability to formulate and institutionalize foreign policy goals. This does put the grouping at a strategic disadvantage in comparison with Western-dominated institutions such as NATO or the EU which have worked out specific foreign policy strategies. As openly rivaling these organizations by emulating them is no practical option, preventing unwanted foreign policy outcomes might well be. This is a more defensive strategy but by no means unimportant.

In fact, BRICS well-known critique against unilateral interventions and regime change can realistically not materialize by militarily preventing NATO or the US to take action (Puri 2016). The global military power balance is still in favor of Western countries. The US alone spends more on defense (\$717bn) than all BRICS countries together $(\$ 355 \mathrm{bn})$ and entertains a global network of alliances and military bases (Global Fire Power Index 2019). Thus, the most viable option is not direct confrontation but strategies of impediment and prevention. BRICS call for a rulebased order and primacy of the UN Security Council also falls within this category. 
From the perspective of geopolitics, the emphasis on rules can be seen as a strategic move which compensates for the still underdeveloped hard power options of the group. The emphasis on Security Council primacy is foremost in line with China's and Russia's position in the Council over which they can exert some influence due to their veto holding position.

When it comes to concrete examples of BRICS influence in geopolitics, two cases stand out. In Syria, BRICS countries and in particular Russia and China successfully prevented the outcome favored by the West, the removal of Assad. This has become evident through the frequent use of the veto by China and Russia and is even more apparent by Russia becoming a warring party to the conflict in support of Assad. BRICS summit declarations were providing tacit support by not challenging Russia's or China's position and by making clear that a replication of the Libyan model (regime change through intervention and military support of rebels against the government) is not to be accepted (BRICS Fortaleza Declaration 2014, para. 27). The emphasis on a Syria-led peace process provides Assad a key role in the future of the country and thus counters the Western preference for him to step down (BRICS eThekwini Declaration 2013, para. 26). In the end, Assad continues to stay in power primarily with the help of the Russian military intervention.

The second example is the attempt to sanction and isolate Russia after its occupation of Crimea. The BRICS group did not follow the EU and US in condemning Russia or implementing sanctions nor did BRICS suspend Russian membership or exert any diplomatic misgivings over the Ukrainian issue. Calls for Russia's exclusion from the G20 were prevented by BRICS. While Russia was expelled from the G8 and there were efforts to remove it from the G20, BRICS foreign ministers declared that "The custodianship of the G20 belongs to all Member States equally and no one Member State can unilaterally determine the exclusion of another Member State from the Summit" (BRICS Foreign Ministers, 24 March 2014). This ended the debate around Russian membership. BRICS countries collectively did not support General Assembly resolution 68/262 which calls upon UN members to "refrain from actions aimed at the partial or total disruption of the national unity and territorial integrity of Ukraine, including any attempts to modify Ukraine's borders through the threat or use of force or other unlawful means;" (UNGA resolution 68/262, 1 April 2014, para. 2). The 2015 BRICS summit which took place in the Russian city of Ufa explicitly supported the so-called Normandy Format and Minsk Agreement as the main regional framework for conflict resolution (Ufa Declaration 2015: 43).

In sum, the group displayed some alignment with Russia's position. Although BRICS did not endorse Russian action in Ukraine, the absence of any critique and the acknowledgement of legitimate Russian concerns can be counted as tacit support. In this context, it was argued that "BRICS countries in general do not feel that the crisis in the Ukraine should be framed in terms of violation of territorial integrity or aggression against a sovereign country" (Brosig 2019: 135). Again the preferred Western narrative of the crisis was opposed. Without a doubt, the cases of Ukraine and Syria are important examples of geopolitics. The extent to which these can be replicated elsewhere remains to be seen. 


\section{Multi-alignment foreign policy}

While there is no common consensus how the current world order is structured, it is obvious that Western dominance is under stress, emerging powers have not yet risen to substantially challenge existing structures and that order remains in flux. Such a situation poses significant challenges on foreign policy makers. Operating in an environment with multiple centers of power, with hegemonic actors as well as dispersed forms of authority requires a foreign policy which corresponds to these realities. In this context, a multi-alignment strategy makes inherently sense.

The supposed weakness of BRICS as only a loose grouping of countries far apart from each other with little prospects for meaningful political or economic integration is not necessarily a failure of design. It can also work to the advantage of its members. BRICS does not aspire to be an alliance. First, the ambition would be hard to realize and policy failure would be difficult to correct afterward. It is a matter of fact that BRICS lacks the material and geographic basis for effective bloc building. It is not representing a geographically coherent region; geopolitical interests are thus disparate at times. Second, bloc building is seen as problematic from a normative perspective as well as from a geostrategic point of view. The BRICS narrative builds on the premise that bloc building/action can lead to more confrontation and polarization favoring established centers of power more than aspiring powers. This rhetoric is often applied against Western concerted efforts to push through certain formulations or positions for example in the Security Council (see Syria).

Third, bloc building, even if it would be possible, it is not automatically an advantage for BRICS countries. Economic links (e.g., trade) between BRICS members are fairly limited, and, thus, real (inter-)dependencies exist overwhelmingly with the US or EU. Access to high technology and large consumer markets is critically important for the further growth of basically all BRICS countries. Thus, openly antagonizing the West is a strategy which is not necessarily in line with long-term economic interests of the group. The consequence is that BRICS members tend to favor multi-alignment over bloc-building.

For a country like India, a multi-alignment strategy provides tangible benefits (Hall 2016). In its security politics, it relies on Russian weaponry but also entertains close relations with the US with which it shares similar strategic interests in the Indo-Pacific Ocean. Joining a foreign policy group which requires choosing either side would be a disadvantage. It also appears questionable that Brazil should risk antagonizing the US, its most vital Northern continental neighbor, over a conflict (e.g., Crimea) which is peripheral to Brazil's security. Bolsonaro favors closer relations than his predecessors to the US while not intending to abandon South-South groupings.

In the end, most countries are members of numerous organizations and groupings and use them flexibly. While this might play out as a disadvantage for the single group, the very essence of a grouping is that it allows for flexibility or multi-alignment without bloc-building. This is not a weakness in itself but might equally be seen as a deliberate or even strategic decision, taking into consideration the group members' individual interests. 


\section{Regional authority}

The implicit operating principles mentioned above provide the advantage of creating and accepting regional backyards or at least promoting regional authority. BRICS meetings are designed not to challenge and criticize its members but to respect individual interests, leaving bi-lateral grievances outside the group while identifying as a non-Western (different) club. This facilitates the carving out of regional backyards. Although a regional backyard is not an officially agreed target as such it is facilitated through the formal and informal operations of the group. As long as no BRICS member is infringed by another one, essential individual national interests are tacitly accepted and thus help in supporting regional authority.

The BRICS geographic spread and relative separation from each other enables the grouping to indirectly support each other's regional position. Although it is true that India and China are placed in a competitive regional setting, this is rather the exception within the BRICS group than the rule. Especially Russian-Chinese security cooperation has overcome past grievances and is now marked by mutual geostrategic support (Charap et al. 2017). On issues like Syria and Venezuela, Russia and China often display the same voting patterns in the Security Council. Countries like Brazil or South Africa are too far apart and too small to compete with either India, China, Russia or with one another. Thus, the opportunity emerges to support if only rhetorically or diplomatically each member's regional authority. More complicated is the relationship between China and India within their own region. Both are regional rivals, and the opportunity for mutual regional recognition of zones of influence is limited.

Tendencies of regional backyard politics can be observed in some instances. Most summits chaired by the rotating host nation are encompassing an outreach program, which is often directed toward the respective region. The 2013 summit in South Africa was the first that started to establish an extensive outreach program. BRICS has sought to cultivate better and wider South-South cooperation through these additional fora. For example, the 2013 summit in Durban adopted a declaration which was explicitly addressing the regional dimension of the meeting being entitled: "BRICS and Africa: Partnership for Development, Integration and Industrialisation." The outreach program invited a dozen of African heads of state and leaders from eight regional economic communities. The event displayed South African continental leadership. The 2013 summit declaration also mentioned the Pretoria favored African Capacity of Immediate Response to Crisis (ACIRC), peacekeeping instrument within the AU which was not finding undisputed continental support. Here, BRICS was lending support the South Africa exercising continental leadership. In hosting the summit, South Africa used the group to promote its regional authority within the AU framework. In 2015, Russia invited the Shanghai Cooperation Organisation (SCO) and members of the Eurasian Economic Union (EAEU) to the Ufa Summit. One year later in Goa, India invited BIMSTEC (Bay of Bengal Initiative for Multi-Sectoral Technical and Economic Cooperation) countries to the meeting. At Xiamen, China in 2017 welcomed delegations from Egypt, Guinea, Tajikistan, Mexico and Thailand. At the event, China started the BRICS 
plus initiative with the aim to set up a more permanent circle of friends of BRICS. While no such additional forum could be institutionalized formally, it is clear that the annual outreach programs have widened their geographical focus beyond a regional dimension and now regularly extend to countries in the emerging markets and developing world which are occupying leadership positions for example Argentina chairing G20, Egypt the G77, Jamaica CARICOM, or Turkey the OIC (Lissovolik 2018). As the invitations to these programs are channeled through the summit hosting country, there is a potential image boosting effect for each host which reaches beyond the BRICS group.

At the geostrategic level, the best example of BRICS facilitating the carving out of regional backyards can be seen in their response to Russia's occupation of Crimea. While BRICS members did not endorse Russia's illegal occupation, Russian action was perceived to be somehow legitimate as it was concerning key Russian national security interests. BRICS tolerated Russian action not because it was seen as legitimate in a narrow legal sense but because it was seen as belonging to Russia's core sphere of security concerns. It is part of the group's principles to respect a member's vital interests as long as there are no direct and negative effects on other members. In the end, the Ukrainian crisis was treated by BRICS almost as a domestic Russian issue and thus facilitated the projection of power in the former Soviet space. Interestingly, the Crimean occupation was not perceived as state-sponsored separatism jeopardizing territorial sovereignty, which BRICS members so often claim when it comes the denouncing Western interventions. Instead the view prevailed that Russian key security interests have not adequately taking into account over revolutionary events happening in the Ukraine (Chacko 2015).

A similar pattern can be seen with regard to Indian and Chinese interests. Here, the issues of Kashmir, the South China Sea or Tibet are worth mentioning. Although BRICS is not endorsing Indian or Chinese territorial claims, the absence of any significant references to these conflicts provides both countries with some political leeway to continue their way without fear of interference from pivotal neighbors at least as far as BRICS statements are concerned. Again, the role BRICS is playing is less one of an active agency but indirect facilitator. While the former would in fact be the best evidence for the relevance of the group, the letter is anything but trivial.

\section{Conclusion}

This article explores the inner working mechanisms and foreign policy value added of the BRICS grouping within the area of security policy. Thereby four key characteristics could be explored. BRICS provides tangible value for its members through: supporting domestic regime stability, managing unwanted external interferences, allowing to follow a multiple alignment strategy and helps extending regional authority. The reason for focusing on the value added of the group is primarily because it is currently not well understood in the literature on rising powers. While critics have pointed to the shortcomings of BRICS as a too disparate group and the narrative of rising powers currently undergoes re-evaluation (see this special issue) 
the main benchmark for evaluating the sustainability of BRICS should be generated from within the group based on its ability to provide foreign policy value.

Not all of the four benefits are equally important for every member all of the time. These four types of benefits are directly linked to the semi-codified and un-codified operating principles of BRICS. Domestic regime stability is linked to the informal agreement that BRICS meetings are no place for criticizing each other, inviting opposition groups, or importing conflicts into the group. Creating a friendly state-led (controlled) and safe environment for leaders is mutually attractive and particularly important in times of increasing domestic pressure and external scrutiny.

The prevention of unwanted external influence is linked to the principle of neoWestphalian sovereignty promoting the idea of non-interference. Sovereignty should ideally be un-constrained by external forces. This has become the clearest on issues of military intervention and opposition to regime change (Libya, Syria and Venezuela). As BRICS is not in a position to dominate global politics, the second best option is to prevent or counter unwelcome action which requires less resources and fewer political or other capital. This could be shown by the prevention of Western policy preferences on Syria and over Ukraine. BRICS played a role in preventing the ousting of Assad and the isolation and sanctioning of Russia following the occupation of Crimea.

Especially because BRICS countries are still at a structural power disadvantage against traditional centers of power counter bloc building is no viable political option and this despite clear misgivings over Western preponderance in the global system. Thus, BRICS navigates between two poles prevention of Western hegemony when necessary and cooperation with the West when possible. From this perspective, the only loose coordination of BRICS and the lack of substance (bloc building) is less a weakness as such but grows out of a foreign policy necessity to allow for multiple alignments.

Maybe the most tangible example of foreign policy value added is the opportunity to boost the regional standing of BRICS countries. This is often done by regional outreach programs at summit meetings. The crisis in Ukraine and to some extent in Syria also demonstrates that BRICS is recognizing core national security interests of its members and provides them with coverage against external critique. BRICS has tacitly recognized but not endorsed Russian action of Crimea and did not stand in the way to the Russian intervention in Syria but rejected the goal of removing Assad as one-sided.

Taking all this together, BRICS does provide for a number of tangible benefits covering a wide spectrum from regime stability to regional authority. Its institutional design and operating principles are a matter of strategic choice growing out of domestic necessities and the context and structure of global politics. They have served the group rather well. There are little reasons to believe that these benefits will be given up easily or that BRICS will be replaced or rapidly defaults into meaninglessness.

\section{Declarations}

Conflict of interest The author declares that he has no known competing financial interests or personal relationships that could have appeared to influence the work reported in this article. 


\section{References}

Abdenur, A. 2016. Rising Powers and International Security: The BRICS and the Syrian Conflict. Rising Powers Quarterly 1(1): 109-133.

Acharya, A. 2014. The End of American World Order. Cambridge: Polity Press.

Blagden, D. 2015. Global Multipolarity, European Security and Implications for UK Grand Strategy: Back to the Future, Once Again. International Affairs 91(2): 333-350.

Breslin, S. 2013. China and the Global Order: Signalling Threat or Friendship? International Affairs 89(3): 615-634.

3rd BRICS Summit, Sanya Declaration 14 April 2011. http://www.brics.utoronto.ca/docs/110414-leade rs.html

4th BRICS Summit, Delhi Declaration, 29 March 2012. http://www.brics.utoronto.ca/docs/120329-delhideclaration.html

5th BRICS Summit, eThekwini Declaration, 27 March 2013. http://www.brics.utoronto.ca/docs/130327statement.html

6th BRICS Summit, Fortaleza Declaration, 15 July 2014. http://www.brics.utoronto.ca/docs/140715leaders.html

7th BRICS Summit, Ufa Declaration, 9 July 2015. http://www.brics.utoronto.ca/docs/150709-ufa-decla ration_en.html

9th BRICS Summit, Xiamen Declaration. 4 September 2017. http://www.brics.utoronto.ca/docs/170904xiamen.html

11th BRICS Summit, Brasilia Declaration, 14 November 2019. http://www.brics.utoronto.ca/docs/ 191114-brasilia.html

BRICS Media Statement on the Meeting of the BRICS Foreign/International Relations Ministers, The Hague, Netherlands, March 24, 2014. http://www.brics.utoronto.ca/docs/140324-foreign.html.

BRICS 2018: Events for South Africa's 2018 BRICS Chairship. http://www.brics2018.org.za/sites/defau 1t/files/Documents/Calendar.pdf. Accessed 3 May 2018.

Brosig, M. 2019. The Role of BRICS in Large-Scale Armed Conflict. Cham: Palgrave Macmillan.

Chacko, P. 2015. Why India Doesn't Support Western Sanctions on Russia. East Asia Forum 6 May 2014. http://www.eastasiaforum.org/2014/05/06/why-india-doesnt-support-western-sanctions-on-russia/. Accessed 19 September 2018.

Charap, S., J. Drennan, and P. Noël. 2017. Russia and China: A New Model of Great-Power Relations. Survival 59(1): 25-42.

De Almeida, P.A. 2010. Never Before Seen in Brazil: Luis Inácio Lula da Silva's Grand Diplomacy. Revista Brasileira De Política Internacional 53(2): 160-177.

De Coning, C., T. Mandrup, and L. Odgaard, eds. 2015. The BRICS and Coexistence An Alternative Vision of World Order. London: Routledge.

Destradi, S. 2010. Regional Powers and Their Strategies: Empire, Hegemony, and Leadership. Review of International Studies 36: 903-930.

Eilstrup-Sangiovanni, M., and S. Hofmann. 2020. Of the Contemporary Global Order, Crisis, and Change. Journal of European Public Policy 27(7): 1077-1089.

Flockhart, T. 2016. The Coming Multi-order World. Contemporary Security Policy 37(1): 3-30.

Global Firepower Index. 2019. https://www.globalfirepower.com/defense-spending-budget.asp. Accessed 11 November 2019.

Gray, K., and C. Murphy. 2013. Introduction: Rising Powers and the Future of Global Governance. Third World Quarterly 34(2): 183-193.

Gvosdev, N. 2012. The Realist Prism: What the US Can Learn from the BRICS. World Politics Review, June 22. https://www.worldpoliticsreview.com/articles/12087/the-realist-prism-what-the-u-s-canlearn-from-the-brics. Accessed 7 May 2018.

Haas, R.N. 2008 The Age of Nonpolarity What Will Follow U.S. Dominance. Foreign Affairs May/June 2008.

Hall, I. 2016. Multialignment and Indian Foreign Policy Under Narendra Modi. The Round Table 105(3): 271-286.

Hart, A., and B. Jones. 2010. How Do Rising Powers Rise? Survival 52(6): 63-88.

Herbst, J. 2007. Crafting regional cooperation in Africa. In Crafting Cooperation Regional International Institutions in Comparative Perspective, ed. A. Acharya and A.I. Johnston, 129-144. Cambridge: Cambridge University Press. 
Hudson, V. 2005. Foreign Policy Analysis: Actor-Specific Theory and the Ground of International Relations. Foreign Policy Analysis 1(1): 1-30.

Hurrell, A. 2006. Hegemony, Liberalism and Global Order: What Space for Would-Be Great Powers? International Affairs 82(1): 1-19.

Kahler, M. 2013. Rising Powers and Global Governance: Negotiating Change in a Resilient Status Quo. International Affairs 89(3): 711-729.

Kenkel, K.M. 2016. Die Talfahrt einer aufstrebenden Macht: Brasiliens Krise und globale Präsenz. GIGA Focus, Lateinamerika, Number 2, Juli 2016.

Kim, H. 2017. Understanding Modi and Minorities: The BJP-Led NDA Government in India and Religious Minorities. India Review 16(4): 357-376.

Kluge, J. 2019. Russlands soziale Schieflage Die Privathaushalte zahlen einen hohen Preis für Russlands makroökonomische Stabilisierung. SWP Aktuell. https://www.swp-berlin.org/publikation/russlandssoziale-schieflage/. Accessed 15 November 2019.

Lipton, M. 2017. Are the BRICS Reformers, Revolutionaries, or Counter-Revolutionaries? South African Journal of International Affairs 24(1): 41-59.

Lissovolik, Yaroslav. 2018. BEAMS of the Sunrise: A Look at BRICS 5-Year Cycles. https://valdaiclub. com/a/highlights/beams-of-the-sunrise-a-look-at-brics-5-year-cycles/. Accessed 16 April 2021.

Nolte, D. 2010. How to Compare Regional Powers: Analytical Concepts and Research Topics. Review of International Studies 36: 881-901.

Pant, H. 2013. The BRICS Fallacy. The Washington Quarterly 36(3): 91-105.

Pauw, J. 2017. The President's Keepers: Those keeping Zuma in Power and Out of Prison. Cape Town: NB Publishers.

Pham, Q., and R. Shilliam, eds. 2016. Meanings of Bandung, Postcolonial Orders and Decolonial Visions. London: Rowman \& Littlefield.

Prys-Hansen, M., and Nolte, D. 2016. BRICS and IBSA: The Clubs of the Rising Powers are Losing Their Lustre. GIGA Focus Global, Number 05, October 2016.

Puri, H. 2016. Perilous Interventions The Security Council and the Politics of Chaos. New York: Harper Collins Publishers.

Ramzy, A., and Buckley, C. 2019. The Xinjiang Papers 'Absolutely No Mercy': Leaked Files Expose How China Organized Mass Detentions of Muslims. The New York Times, 16 November 2019. https://www.nytimes.com/interactive/2019/11/16/world/asia/china-xinjiang-documents.html? action $=$ click\&module $=$ Top $\% 20$ Stories\&pgtype $=$ Homepage. Accessed 17 November 2019.

Rakove, R. 2018. Bandung Conference (1955). In The Encyclopedia of Diplomacy.

Safi, M. 2017. Chinese and Indian troops face off in Bhutan border dispute. The Guardian, 6 July 2017. https://www.theguardian.com/world/2017/jul/06/china-india-bhutan-standoff-disputed-territory. Accessed 11 November 2019.

Saran, S. 2020. Resisting Chinese Encroachment. https://www.orfonline.org/research/resisting-chineseencroachment-68917/, Observer Research Foundation, 2 July 2020. Accessed 11 September 2020.

Shepsle, K. 2008. Rational Choice Institutionalism. In The Oxford Handbook of Political Institutions, ed. Sarah A. Binder, R.A.W. Rhodes, and Bert A. Rockman. Oxford: Oxford University Press.

Söderbaum, F. 2013. Rethinking Regions and Regionalism. Georgetown Journal of International Affairs 14(2): 9-18.

Stewart-Ingersoll, R., and D. Frazier. 2012. Regional Powers and Security Orders. A Theoretical Framework. London: Routledge.

Stuenkel, O. 2015a. The BRICS and the Future of Global Order. Lanham: Lexington Books.

Stuenkel, O. 2015b. Post Western World. Cambridge, Malden: Polity.

Thakur, R. 2014. How Representative are Brics? Third World Quarterly 35(10): 1791-1808.

UN General Assembly, Resolution 68/262, Territorial Integrity of Ukraine, New York: 1 April 2014.

Vieira, M. 2012. Rising States and Distributive Justice: Reforming International Order in the TwentyFirst Century. Global Society 26(3): 311-326.

Wigell, M. 2016. Conceptualizing Regional Powers' Geoeconomic Strategies: Neo-imperialism, Neomercantilism, Hegemony, and Liberal Institutionalism. Asia Europe Journal 14: 135-151.

Worldometer. 2021. Covid-19 Corona Virus Pandemic. https://www.worldometers.info/coronavirus/. Accessed 27 July 2020.

Zondo Commission. The Judicial Commission of Inquiry into Allegations of State Capture. https://www. sastatecapture.org.za/. 
Has BRICS lost its appeal? The foreign policy value added of...

Publisher's Note Springer Nature remains neutral with regard to jurisdictional claims in published maps and institutional affiliations. 